Galaxea, JCRS, 8: 61-69 (2006)

\title{
Preliminary survey and diet analysis of seagrass bed fishes at Mauritius, western Indian Ocean
}

\author{
Yohei Nakamura ${ }^{*}$, Hiroaki Terashima ${ }^{2,3}$, Samyan Chettanand ${ }^{4 * *}$, Naoshi Sato ${ }^{3}$ \\ and Hitoshi Ida ${ }^{3}$
}

\begin{abstract}
${ }^{1}$ Department of Global Agricultural Sciences, Graduate School of Agricultural and Life Sciences, The University of Tokyo, Yayoi, Bunkyo-ku, Tokyo 1138657, Japan.

${ }^{2}$ Expert dispatched from Japan International Cooperation Agency for the Coastal Fisheries Resources and Environment Conservation Project, Albion Fisheries Research Centre, Ministry of Fisheries, Petite Riviere, Mauritius

${ }^{3}$ School of Fisheries Sciences, Kitasato University, Ohfunato, Iwate 022-0101, Japan

${ }^{4}$ Albion Fisheries Research Centre, Ministry of Fisheries, Albion, Petite Riviere, Mauritius
\end{abstract}

\begin{abstract}
Fish faunas and diets were examined in Halodule uninervis- and Syringodium isoetifolium-dominated seagrass beds at Mauritius, western Indian Ocean, in March 2002. A total of 37 fish species (representing 16 families) were collected, 26 (14 families) of them occurring in the $H$. uninervis-bed and 26 (13 families) in the $S$. isoetifolium-bed, with 15 (10 families) common to both beds. Fishes were mainly juveniles, dominant families with regard to both species and individual numbers being Apogonidae, Mullidae, Labridae, Scaridae and Gobiidae. Zoobenthivores comprised the most dominant feeding type in both seagrass beds, harpacticoid copepods and gammaridean amphipods being the most important food resources for those fishes.
\end{abstract}

Key words: Fish, Seagrass bed, Diet, Mauritius, Western Indian Ocean

${ }^{*}$ Corresponding author : Y. Nakamura

E-mail: ynakamura@ori.u-tokyo.ac.jp

TEL. +81-3-5351-6527, FAX. +81-3-5351-6498

*Present address: Department of Living Marine Resources, Ocean Research Institute, The University of Tokyo, Minamidai 1-15-1, Nakano-ku, Tokyo 164-8639, Japan

**Present address: Mauritius Oceanography Institute, 4th Floor, France Centre, Victoria Avenue, Quatre-Bornes, Mauritius

\section{INTRODUCTION}

Seagrasses, which are widely distributed in both tropical and temperate coastal waters, comprise one of the earth's most productive aquatic ecosystem types (Hemminga and Duarte 2000). Due to their high primary production and complex habitat structure, seagrass beds support a variety of sessile and mobile organisms. Many fish species, including a number of commercial value, are attracted to seagrass habitats for foraging and shelter, especially during their juvenile life-stages (Bell and Pollard 1989). Although many seagrass bed fish studies have been conducted worldwide (Pollard 1984), such research in the western Indian Ocean (WIO) is still scarce (Gullström et al. 2002), especially for the Island States, including the Seychells, Comoros, Réunion, 
Mauritius and Madagascar (but see, HarmelinVivien 1983).

In recent years, seagrass bed systems have been under stress due to inadequate management and their vulnerability to human-related activities (Hemminga and Duarte 2000). Mauritian seagrass beds, in particular, continue to be removed by hotels in the belief that they are unsightly or harbour organisms causing injury to bathers (Daby 2003). Under such circumstances, an understanding of seagrass bed fish faunas and their diets is urgently required, being basic factors for effective coastal management and conservation of coastal fish diversity and fisheries resources in Mauritius.

This is the first quantitative seagrass bed fish study in Mauritius aiming to address the following questions: (1) What kinds of fishes utilize the seagrass beds in Mauritius and do different seagrass species support distinct fish communities? (2) What are important food resources for Mauritian seagrass bed fishes?

\section{MATERIALS AND METHODS}

\section{Study area}

Mauritius, located in the western Indian Ocean $800 \mathrm{~km}$ east of Madagascar $(2000 \mathrm{~km}$ from the African coast) (Fig. 1), is a small volcanic island of nearly $1865 \mathrm{~km}^{2}$ surrounded by a shallow fringing coral reef and barrier reef along $150 \mathrm{~km}$ of coastline (Terashima et al. 2001). The surrounding lagoons vary in size from a few hundred meters to a few kilometers in width, especially off the eastern coast. Water depths of the lagoons are shallow $(<2 \mathrm{~m})$, with weak tidal variations $(c a .0 .5 \mathrm{~m})$. The climate is between tropical and subtropical, water temperatures oscillating between $22^{\circ} \mathrm{C}$ (August to September) and $28^{\circ} \mathrm{C}$ (January to April).

Two sampling sites were established along the western coast of Mauritius at Albion and La Preneuse (Fig. 1). Although 7 seagrass species have been recorded in Mauritius (Green and Short 2003), the bed at Albion was dominated

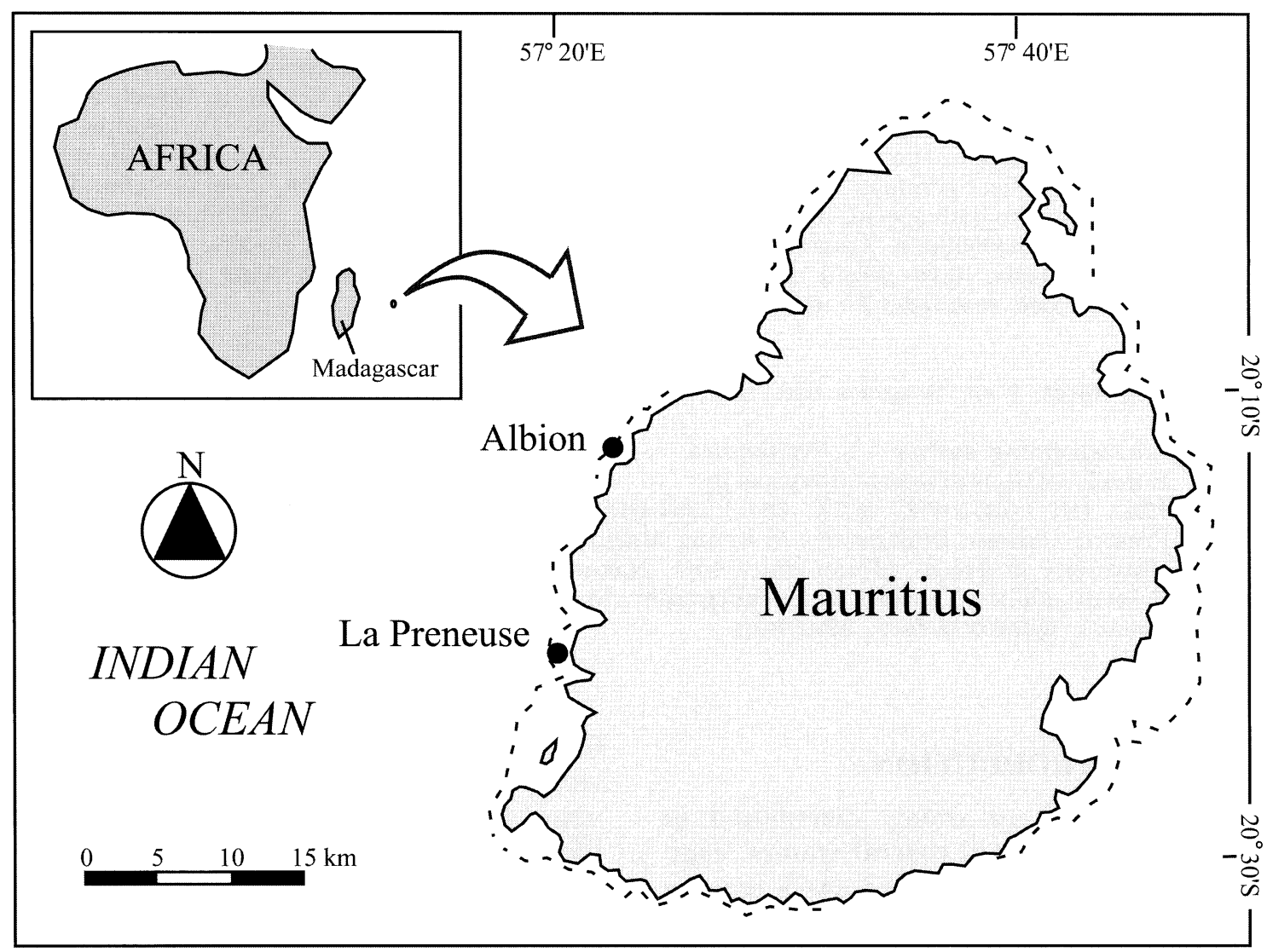

Fig. 1. Map of the sampling sites at Mauritius, Indian Ocean. Dotted line indicates reef margin. 
by Halodule uninervis, whereas that at La Preneuse was dominated by Syringodium isoetifolium. Each species formed dense vegetation, the leaf height varying from 8 to $15 \mathrm{~cm}$. Both seagrass beds extended into inshore lagoons and were not $\mathrm{ex}^{-}$ posed during low tide.

\section{Sampling design}

Eleven replicate 1-min tows were taken at each seagrass bed site with a seine net $(8 \mathrm{~m}$ long, 1 $\mathrm{m}$ height, $5 \mathrm{~mm}$ mesh) towed at a speed of 0.6 $\mathrm{kn}$ ( $c a .100 \mathrm{~m}^{2}$ covered by each tow). Sampling was completed between 1000 and 1600hrs in March 2002 , owing to the presence of many juvenile and adult fishes in Mauritian lagoons during that season (N. Sato, unpubl. data).

Immediately after fish collection, concentrated formalin was injected into the body cavity of each specimen, which was then preserved in $10 \%$ formalin. In the laboratory, fishes were identified (e.g. Fricke 1999; Nakabo 2002) and standard lengths (SL) measured to the nearest 0.1 $\mathrm{mm}$. Individual fishes were recorded as adults or juveniles on the basis of gonad maturation, body size, and/or published information (e.g. Myers 1999). Food items in the gut contents of each specimen were identified to the lowest possible taxon. The percentage volume of each food item in the diet was visually estimated under a binocular microscope as follows: gut contents were squashed on the $1 \times 1 \mathrm{~mm}$ grid slide to a uniform depth of $1 \mathrm{~mm}$ and the area taken up by each item measured. The latter was then divided by the total area of the gut contents to calculate the percentage volume of that item in the diet. Food resource use was expressed as mean percentage composition of each item by volume, being calculated by dividing the sum total of the individual volumetric percentage for the item by the number of specimens examined. Specimens with empty stomachs were excluded from the analysis. Each fish species was then assigned to one of six trophic groups on the basis of diet ; herbivores (feeding mainly on plant material), detritivores (feeding mainly on detritus), zoobenthivores (hereafter, benthivores) (feeding mainly on benthic invertebrates, such as crustaceans, polychaetes, and molluscs), planktivores (feeding mainly on zooplankton), piscivores (feeding mainly on fish) and omnivores (feeding on plant as well as animal material). Important food resources of fishes in each seagrass bed were determined on the basis of cumulative percentage volume values of all fishes for each food item and the percentage of fish species consuming each food item. Commercial values of fishes in local markets were also assessed, based on Terashima et al. (2001).

\section{RESULTS}

A total of 764 individuals representing 37 species in 16 families were collected from the two seagrass beds (Appendix I). Of these, 263 individuals (26 species representing 14 families) were collected from Albion and 501 (26 species in 13 families) from La Preneuse. Fifteen species (10 families) (hereafter, termed as 15 common species) occurred in both seagrass beds. Among the 15 common species, the densities of 4 differed significantly between the beds (Appendix I). Clear differences in body size of the 15 common species were not apparent between the two seagrass beds.

In terms of species number per family at Albion, Mullidae and Scaridae (4 species, 15.4\% each) were the most dominant, followed by Labridae (3 species, 11.5\%). In terms of individual numbers, Gobiidae (25.9\%), Labridae (20.2\%) and Apogonidae (12.5\%) were dominant. At La Preneuse, Scaridae (4 species, 15.4\%), Apogonidae and Mullidae (3 species, $11.5 \%$ each) were the most dominant for species number, and Siganidae (47.7\%), Labridae (19.2\%), and Pomacentridae (7.4\%) were the most dominant for the number of individuals. The most dominant species in the seagrass bed at Albion were Asterropteryx semipunctata (22.4\% of total), Stethojulis strigiventer (18.6\%), and Epinephelus merra (12.2\%). At La Preneuse, on the other hand, Siganus sutor (41.1\%), S. strigiventer $(19.0 \%)$, and Siganus rivulatus $(6.6 \%)$ were dominant. Fishes collected were mainly juveniles $(78.9 \%$ of total individuals in Albion and $97.0 \%$ in La Preneuse), including commercial species (Appendix I).

A total of 676 individuals (37 species) were used for the dietary analysis (Fig. 2), the data for each of the 15 common species being pooled across the two seagrass beds, because clear dietary composition differences were not observed (Mann-Whitney $U$ test, $P>0.05$ for the most dominant food item in each species). Benthivores were found to be the most dominant feeding category in both seagrass beds (Fig. 3), harpacticoid copepods and gammaridean amphipods being the most important food resources for those fishes (Table 1). Although clear differences in species' richness and individual numbers of most trophic groups were not observed between the two beds 
(Fig. 3), means and variances of individual numbers of herbivores were much greater at La Preneuse than at Albion. Herbivores fed mainly on filamentous algae, but two Siganus species took also seagrasses. Non-exclusive seagrass feeding was also observed in the detritivorous parrotfishes
Calotomus spinidens and Leptoscarus vaigiensis (body size with larger than $60 \mathrm{~mm} \mathrm{SL}$ ). Piscivores fed predominantly on Asterropteryx semipunctata (one of two individuals of Saurida gracilis and eight of nine individuals of Aulostomus chinensis).

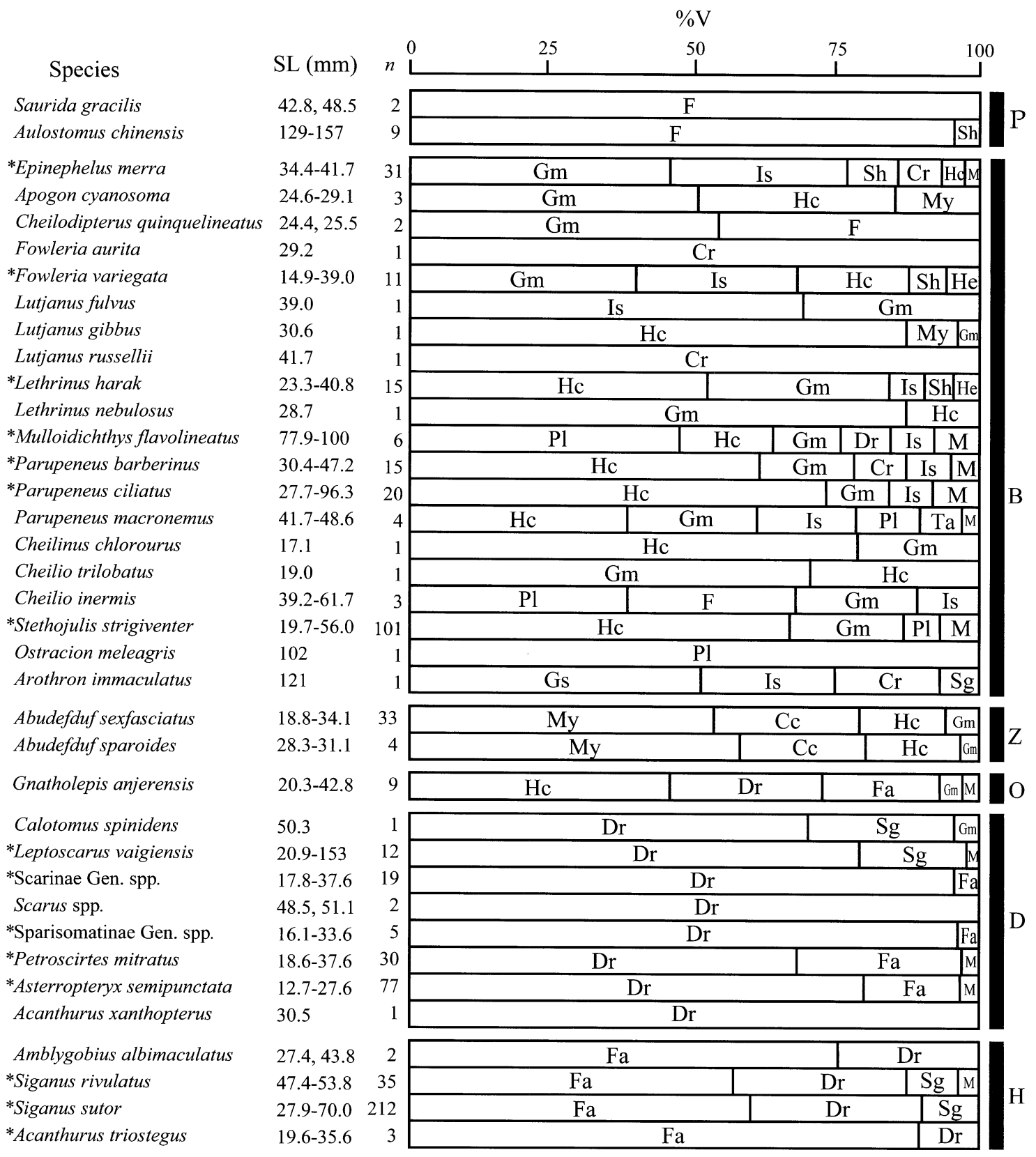

Fig. 2. Mean percentage volume of food items of each species. $C c$, calanoid copepods; $C r$, crabs; $D r$, detritus; $F a$, filamentous algae; $F$, fishes; $G m$, gammaridean amphipods; $H c$, harpacticoid copepods; $H e$, hermit crabs; Is , isopods; $M y$, mysids; $P l$, errant polychaetes; $S g$, seagrasses; $S h$, shrimps; $T a$, tanaids; $M$, items composing less than $3 \%$ of gut content volume. SL, standard length; $n$, number of fish examined containing food. The assemblage was divided into six trophic groups: $\mathrm{P}$, piscivore; B, benthivore; Z, planktivore; O, ominivore; D, detritivore; H, hervivore. Species marked with an asterisk occurred at both Albion and La Preneuse. 

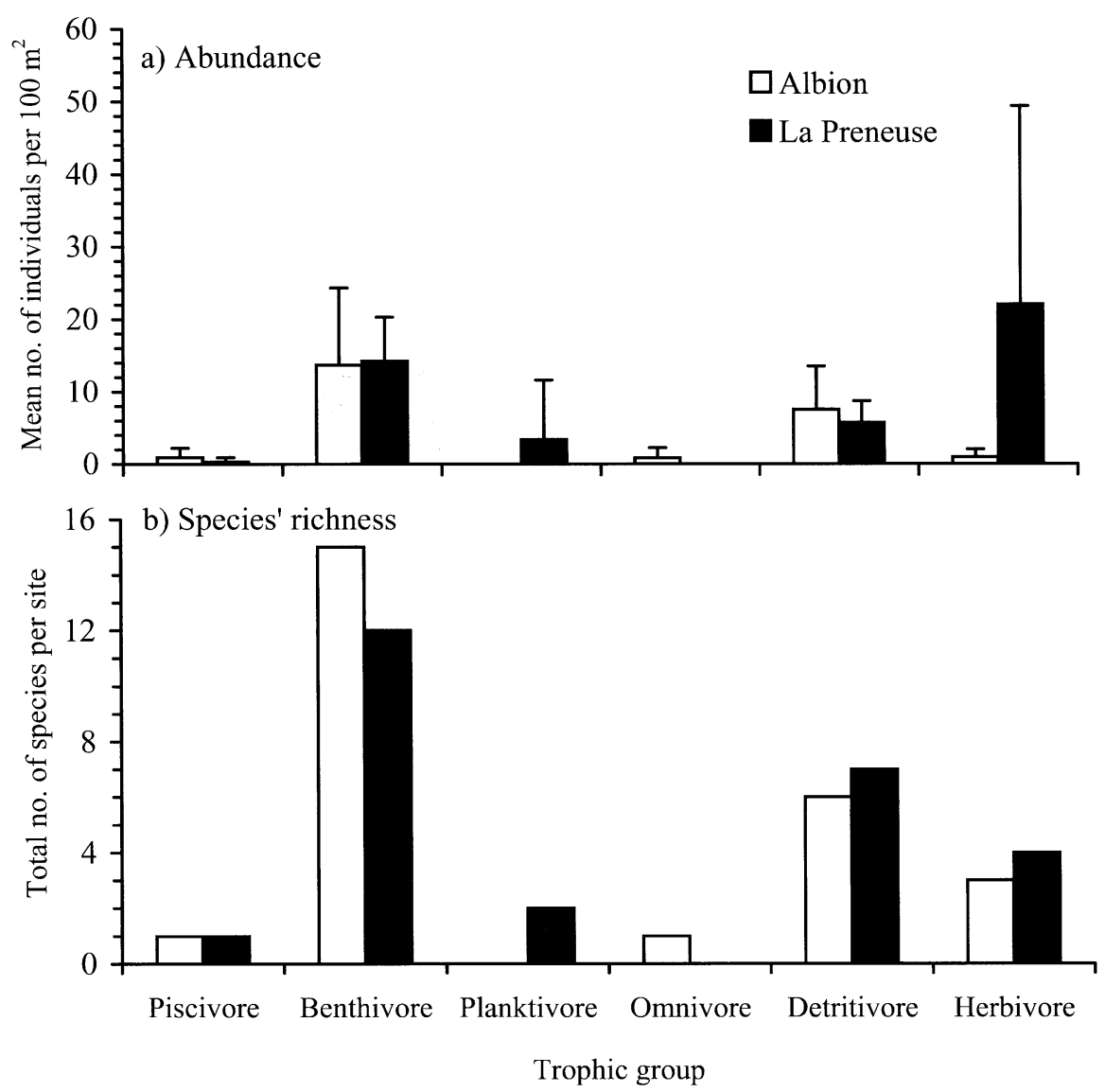

Fig. 3. Variations in (a) mean abundance (number of individuals per $100 \mathrm{~m}^{2}$ ) and (b) species' richness of six trophic groups at Albion and La Preneuse. Vertical bar represents one standard deviation.

Table 1. Cumulative percentage volume (\%V) values for each important food item (listed in decreasing order) and percentage of fish species consuming each item $(\% \mathrm{~F})$ at Albion and La Preneuse (26 species each)

\begin{tabular}{|c|c|c|c|c|c|}
\hline \multicolumn{3}{|l|}{ Albion } & \multicolumn{3}{|c|}{ La Preneuse } \\
\hline Food items & $\% \mathrm{~V}$ total & $\% \mathrm{~F}$ & Food items & $\% \mathrm{~V}$ total & $\% \mathrm{~F}$ \\
\hline Detritus & 538 & 46 & Detritus & 772 & 50 \\
\hline Gammaridean amphipods & 433 & 62 & Harpacticoid copepods & 621 & 65 \\
\hline Filamentous algae & 349 & 35 & Gammaridean amphipods & 303 & 42 \\
\hline Harpacticoid copepods & 296 & 35 & Filamentous algae & 301 & 31 \\
\hline Isopods & 280 & 42 & Mysids & 152 & 15 \\
\hline Errant polychaetes & 204 & 23 & Crabs & 133 & 15 \\
\hline Fishes & 182 & 12 & Fishes & 100 & 4 \\
\hline Crabs & 133 & 15 & Shrimps & 66 & 23 \\
\hline
\end{tabular}




\section{DISCUSSION}

Harmelin-Vivien (1983) reported that Apogonidae, Labridae, and Gobiidae were dominant families (numbers of species and individual numbers) in multi-species seagrass beds at Tuléar, southwest Madagascar. A similar situation occurred in the present seagrass beds, the above three families plus Mullidae and Scaridae being dominant. Dominance of these families has also been reported from tropical seagrass beds in the western Pacific (WP) region (Guam Island, Jones and Chase 1975; Yaeyama Islands, Nakamura and Sano 2004), as suggested by Pollard's study (1984), which showed a high similarity at the family level beteen seagrass fish assemblages in the tropical WP and Indian Ocean, compared with other regions. Furthermore, 18 of 37 species in the present study have also been commonly observed in tropical WP seagrass beds (Appendix I), three species (Stethojulis strigiventer, Parupeneus barberinus, and Asterropteryx semipunctata) being abundant in both the WIO and tropical $\mathrm{WP}$, indicating that seagrass fish faunas in the WIO are similar to those in the tropical WP at both the family and species levels.

Although some species occurred exclusively in Halodule- or Syringodium-dominated beds (11 species each), the individual numbers recorded of each were low (< total 4 individuals, respectively, except for 10 individuals of Aulostomus chinensis). Fifteen species, on the other hand, occurred in both seagrass beds, most being abundant with similar body size classes in each bed. These results indicate that the two seagrass beds somewhat similar as habitats for Mauritian coastal fishes, even though dominated by different seagrass species.

As has been the case in other seagrass bed fish studies worldwide, fishes collected in this study were mainly at juvenile life-stages, including commercially valuable species which usually inhabit coral reefs at later stages (Nakamura person. obser.). Seagrass beds are clearly utilized temporarily as juvenile habitats by a number of species, such utilization by juvenile Serranidae, Lethrinidae, Mullidae, Scaridae, and Siganidae having been reported from other tropical regions (e.g. Roberts 1996; Nagelkerken et al. 2000; Nakamura and Sano 2004).

In the present study areas, benthivores were the most dominant group, the most important food item for these fishes being harpacticoid co- $^{-}$ pepods and gammaridean amphipods, findings that support those for seagrass bed fishes in other regions (Bell and Pollard 1989). Reefassociated seagrass beds harbour greater densities and biomass of such invertebrates than adjacent unvegetated habitats (Ansari et al. 1991; Nakamura and Sano 2005), suggesting that the present seagrass beds might provide abundant food resources for benthivorous fishes. Although detritivores are thought to be a minor trophic group among seagrass bed fishes (Bell and Pollard 1989), many fishes fed on detritus in this study, a similar result to that obtained at Iriomote Island, southern Japan (Nakamura et al., 2003). Seagrass materials observed in the stomach contents of two detritivorous scarid species, Leptoscarus vaigiensis (> 60mm SL) and Calotomus spinidens, may be related to their ontogenetic food preference changes from detritus to plant material (Nakamura et al. 2003). The most abundant herbivorous fishes were Siganus sutor, followed by S. rivulatus (Appendix I). These siganid juveniles often form schools (Woodland 1990), accounting for the large numbers of herbivores at La Preneuse.

Clearly the temporal aspects of this study were limited, seasonal variations in fish fauna and food availability possibly influencing the above results. Despite these limitations, the study provided important baseline data for future investigations of Mauritian seagrass bed fishes.

\section{ACKNOWLEDGEMENTS}

We would like to thank the Albion Fisheries Research Centre (AFRC), Ministry of Fisheries, Mauritius and the Japan International Cooperation Agency (JICA) for logistic support. We also thank M. Sano, H. Kawasaki, S. Harima, H. Iwamoto, R.M. Pillay, M.D. Hurbungs, M.I. Jehangeer, and M. Munbodh for their invaluable assistance. Constructive comments on the manuscript from M. Sano, G. Hardy and anonymous reviewers were much appreciated. This study was undertaken as a part of the Coastal juvenile fish research project promoted by H. Ida and the Coastal Fisheries Resources and Environmental Conservation project undertaken by AFRC and JICA, and supported in part by the 21st Century COE Program of the University of the Ryukyus.

\section{REFERENCES}

Ansari ZA, Rivonker CU, Ramani P, Parulekar $\mathrm{AH}$ (1991) Seagrass habiat complexity and 
macroinvertebrate abundance in Lakshadweep coral reef lagoons, Arabian Sea. Coral Reefs 10: $127-131$

Bell JD, Pollard DA (1989) Ecology of fish assemblages and fisheries associated with seagrasses. In: Larkum AWD, McComb AJ, Shepherd SA (eds) Biology of seagrasses. Elesevier, Amsterdam, pp 565-609

Daby D (2003) Effects of seagrass bed removal for tourism purposes in a Mauritian Bay. Environ Poll 125: 313-324

Fricke R (1999) Fishes of the Mascarene Islands (Réunion, Mauritius, Rodriguez), an annotated checklist, with descriptions of new species. Koelts scientific books, Koenigstein, Germany, 759pp

Green EP, Short FT (2003) World atlas of seagrasses. University of California Press, London, 298pp

Gullström M, de la Torre Castro M, Bandeira SO, Björk M, Dahlberg M, Kautsky N, Rö nnbäck P, Öhman MC (2002) Seagrass ecosystems in the Western Indian Ocean. Ambio 31: 588-596

Harmelin-Vivien ML (1983) Étude comparative de l'ichthyofaune des herbiers de Phanerogames marines en milieux tropical et tempéré. Rev Ecol 38: 179-210

Hemminga MA, Duarte CM (2000) Seagrass ecology. Cambridge University Press, New York, 298pp

Jones RS, Chase JA (1975) Community structure and distribution of fishes in an enclosed high island lagoon in Guam. Micronesica 11: 127148

Myers RF (1999) Micronesian reef fishes: a comprehensive guide to the coral reef fishes of Micronesia, 3rd ed. Coral Graphics, Guam, $330 \mathrm{pp}$

Nagelkerken I, van der Velde G, Gorissen MW, Meijer GJ, van't Hof T, den Hartog C (2000) Importance of mangroves, seagrass beds and shallow coral reef as a nursery for important coral reef fishes, using a visual census technique. Estur Coast Shelf Sci 51: 31-44

Nakabo T (ed)(2002) Fishes of Japan with pictorial keys to the species, English edition. Tokai University Press, Tokyo, 1749pp

Nakamura Y, Horinouchi M, Nakai T, Sano M (2003) Food habits of fishes in a seagrass bed on a fringing coral reef at Iriomote Island, southern Japan. Ichthyol Res 50: 15-22

Nakamura Y, Sano M (2004) Comparison between community structures of fishes in Enhalus acoroides- and Thalassia hemprichii- dominated seagrass beds on fringing coral reefs in the Ryukyu Islands, Japan. Ichthyol Res 51: 38-45

Nakamura Y, Sano M (2005) Comparison of invertebrate abundance in a seagrass bed and adjacent coral and sand areas at Amitori Bay, Iriomote Island, Japan. Fish Sci 71: 543550

Pollard DA (1984) A review of ecological studies on seagrass-fish communities, with particular reference to recent studies in Australia. Aquat Bot 18: 3-42

Roberts CM (1996) Settlement and beyond: population regulation and community structure of reef fishes. In: Polunin NVC, Roberts CM (eds) Reef Fisheries. Chapman and Hall, New York, pp 85-112

Terashima H, Mosaheb J, Paupiah CN, Chineah V (2001) Field guide to coastal fishes of Mauritius. Albion Fisheries Research Centre, Ministry of Fisheries, Albion, Petite Riviere, Mauritius, $191 \mathrm{pp}$

Woodland DJ (1990) Revision of the fish family Siganidae with descriptions of two new species and comments on distribution and biology. Indo-Pacific Fishes, 136pp

(Received: 21 Dec. 2005/Accepted: 20 Apr. 2006)

西インド洋モーリシアス島の海草藻場に出現する魚類 相とその食性

中村洋平 ${ }^{1}$, 寺島裕晃 ${ }^{2}$, Samyan Chettanand ${ }^{3}$ 佐藤直司 $^{2}$, 井田齊 ${ }^{2}$

${ }^{1}$ 東京大学大学院農学生命科学研究科（現 東京大学 海洋研究所)

2 北里大学大学院水産学研究科

${ }^{3}$ モーリシアス共和国水産省アルビオン水産研究所 (現 モーリシアス海洋研究所)

インド洋西部に位置するモーリシアス島沿岸におい て，ウミジグサおよびボウバアマモが優占する海草藻 場（以下，藻場）に出現する魚類相とその食性を調査 した。両藻場で採集された魚類37種 (16科) のうち, 前者の藻場に出現した魚類は 26 種 (14科) で, 後者 の藻場に出現した魚類は 26 種（13科）であった。ま た, どちらの藻場にも出現する魚類は 15 種（10科） であった。採集された個体の多くは稚魚で, 種数と個 体数ともに優占する科は, テンジクダイ科, ヒメジ科, ベラ科, ブダイ科，八ゼ科であった。食性群では，両 藻場ともに底生無脊椎動物食魚が最も多く, これらの 魚類は主にハルパクチクス類やヨコエビ類を摂餌して いた。 
Appendix I. Mean number of individuals (SD) per trawl $\left(100 \mathrm{~m}^{2}, n=11\right)$ of each fish species collected in seagrass beds at Albion and La Preneuse in March, 2002

\begin{tabular}{|c|c|c|c|c|c|c|}
\hline & \multicolumn{2}{|c|}{ Albion } & \multicolumn{2}{|c|}{ La Preneuse } & \multirow[b]{2}{*}{$\begin{array}{c}\text { Life } \\
\text { stage }^{\dagger+}\end{array}$} & \multirow[b]{2}{*}{$\begin{array}{c}\text { Commercial } \\
\text { value }^{+H}\end{array}$} \\
\hline Family/Species & $\begin{array}{c}\text { Mean number } \\
\pm \mathrm{SD}\end{array}$ & $\begin{array}{l}\text { Size range } \\
(\mathrm{SL}, \mathrm{mm})\end{array}$ & $\begin{array}{c}\text { Mean number } \\
\pm \mathrm{SD}\end{array}$ & $\begin{array}{l}\text { Size range } \\
(\mathrm{SL}, \mathrm{mm})\end{array}$ & & \\
\hline \multicolumn{7}{|l|}{ Synodontidae } \\
\hline *Saurida gracilis & - & - & $0.3 \pm 0.6$ & $42.8-49.5$ & $J-3$ & Yes \\
\hline \multicolumn{7}{|l|}{ Aulostomidae } \\
\hline${ }^{*}$ Aulostomus chinensis & $0.9 \pm 1.3$ & $129.7-170.5$ & - & - & $J-10$ & \\
\hline \multicolumn{7}{|l|}{ Serranidae } \\
\hline Epinephelus merra & $2.9 \pm 3.3$ & $34.4-41.7$ & $1.0 \pm 1.2$ & $35.0-39.7$ & $\mathrm{~J}-43$ & Yes \\
\hline \multicolumn{7}{|l|}{ Apogonidae } \\
\hline Apogon cyanosoma & - & - & $0.3 \pm 0.9$ & $24.6-29.1$ & J-3 & \\
\hline *Cheilodipterus quinquelineatus & $0.4 \pm 0.6$ & $24.4-40.3$ & - & - & $\mathrm{J}-3, \mathrm{~A}-1$ & \\
\hline Fowleria aurita & - & - & $0.1 \pm 0.3$ & 29.2 & $J-1$ & \\
\hline Fowleria variegata & $2.6 \pm 5.6$ & $14.0-41.2$ & $0.6 \pm 1.2$ & $15.0-39.0$ & $\mathrm{~J}-28, \mathrm{~A}-8$ & \\
\hline \multicolumn{7}{|l|}{ Lutjanidae } \\
\hline Lutjanus fulvus & $0.1 \pm 0.3$ & 39.0 & - & - & $\mathrm{J}-1$ & \\
\hline *Lutjanus gibbus & - & - & $0.1 \pm 0.3$ & 30.6 & $J-1$ & \\
\hline Lutjanus russellii & $0.1 \pm 0.3$ & 41.7 & - & - & $J-1$ & \\
\hline \multicolumn{7}{|l|}{ Lethrinidae } \\
\hline *Lethrinus harak & $0.3 \pm 0.6$ & $32.9-40.8$ & $1.3 \pm 1.5$ & $23.3-30.8$ & $\mathrm{~J}-17$ & Yes \\
\hline *Lethrinus nebulosus & - & - & $0.1 \pm 0.3$ & 28.7 & $J-1$ & Yes \\
\hline \multicolumn{7}{|l|}{ Mullidae } \\
\hline Mulloidichthys flavolineatus & $0.6 \pm 1.2$ & $81.2-100$ & $0.1 \pm 0.3$ & 77.9 & $\mathrm{~J}-7$ & \\
\hline *Parupeneus barberinus & $1.0 \pm 1.2$ & $30.4-47.2$ & $0.6 \pm 0.9$ & $31.0-36.8$ & $\mathrm{~J}-15$ & Yes \\
\hline *Parupeneus ciliatus & $0.4 \pm 0.6$ & $29.6-35.6$ & $1.3 \pm 1.3$ & $27.7-63.4,96.3$ & $J-21$ & \\
\hline Parupeneus macronemus & $0.4 \pm 0.6$ & $41.7-48.6$ & - & - & $\mathrm{J}-4$ & Yes \\
\hline \multicolumn{7}{|l|}{ Pomacentridae } \\
\hline Abudefduf sexfasciatus & - & - & $3.0 \pm 7.5$ & $18.8-34.1$ & J-33 & \\
\hline Abudefduf sparoides & - & - & $0.4 \pm 0.8$ & $28.3-31.1$ & $\mathrm{~J}-4$ & Yes \\
\hline \multicolumn{7}{|l|}{ Labridae } \\
\hline Cheilinus chlorourus & - & - & $0.1 \pm 0.3$ & 17.1 & $J-1$ & \\
\hline Cheilinus trilobatus & $0.1 \pm 0.3$ & 19.0 & - & - & $\mathrm{J}-1$ & \\
\hline${ }^{*}$ Cheilio inermis & $0.3 \pm 0.5$ & $39.2-61.7$ & - & - & $\mathrm{J}-3$ & \\
\hline *Stethojulis strigiventer & ${ }^{\mathrm{a}} 4.5 \pm 2.7$ & $19.7-56.0$ & b $8.6 \pm 3.9$ & $20.2-55.0$ & $\mathrm{~J}-143, \mathrm{~A}-1$ & \\
\hline \multicolumn{7}{|l|}{ Scaridae } \\
\hline *Calotomus spinidens & $0.1 \pm 0.3$ & 50.3 & - & - & $\mathrm{J}-1$ & \\
\hline *Leptoscarus vaigiensis & $0.6 \pm 0.9$ & $24.7-61.0,153$ & $0.5 \pm 1.0$ & $20.9-45.5$ & $\mathrm{~J}-11, \mathrm{~A}-1$ & \\
\hline *Scarinae Gen. spp. & $0.9 \pm 1.4$ & $18.4-37.6$ & $0.7 \pm 1.8$ & $17.8-24.4$ & $\mathrm{~J}-19$ & Yes \\
\hline *Scarus spp. & - & - & $0.2 \pm 0.4$ & $48.5,51.1$ & $\mathrm{~J}-2$ & Yes \\
\hline *Sparisomatinae Gen. spp. & $0.2 \pm 0.4$ & $16.1,33.6$ & $0.4 \pm 0.6$ & $19.4-27.3$ & $\mathrm{~J}-5$ & Yes \\
\hline
\end{tabular}




\begin{tabular}{|c|c|c|c|c|c|c|}
\hline & \multicolumn{2}{|c|}{ Albion } & \multicolumn{2}{|c|}{ La Preneuse } & \multirow[b]{2}{*}{$\begin{array}{c}\text { Life } \\
\text { stage }^{\dagger \dagger}\end{array}$} & \multirow[b]{2}{*}{$\begin{array}{c}\text { Commercia } \\
\text { value }^{++\dagger}\end{array}$} \\
\hline Family/Species & $\begin{array}{c}\text { Mean number } \\
\pm \mathrm{SD}\end{array}$ & $\begin{array}{l}\text { Size range }{ }^{\dagger} \\
(\mathrm{SL}, \mathrm{mm})\end{array}$ & $\begin{array}{c}\text { Mean number } \\
\pm \mathrm{SD}\end{array}$ & $\begin{array}{c}\text { Size range }{ }^{\dagger} \\
(\mathrm{SL}, \mathrm{mm})\end{array}$ & & \\
\hline \multicolumn{7}{|l|}{ Blenniidae } \\
\hline *Petroscirtes mitratus & ${ }^{\mathrm{a}} 0.5 \pm 0.7$ & $23.6-37.6$ & ${ }^{\mathrm{b}} 2.3 \pm 1.7$ & $18.6-36.8$ & $J-30$ & \\
\hline \multicolumn{7}{|l|}{ Gobiidae } \\
\hline Amblygobius albimaculatus & - & - & $0.2 \pm 0.4$ & $27.4,43.8$ & $\mathrm{~J}-2$ & \\
\hline *Asterropteryx semipunctata & ${ }^{\mathrm{a}} 5.4 \pm 4.6$ & $15.6-27.6$ & ${ }^{\mathrm{b}} 1.6 \pm 2.1$ & $12.7-27.6$ & $\mathrm{~J}-25, \mathrm{~A}-52$ & \\
\hline Gnatholepis anjerensis & $0.8 \pm 1.4$ & $20.3-42.8$ & - & - & $\mathrm{J}-3, \mathrm{~A}-6$ & \\
\hline \multicolumn{7}{|l|}{ Siganidae } \\
\hline Siganus rivulatus & $0.2 \pm 0.4$ & $51.7,53.8$ & $3.0 \pm 6.3$ & $47.4-53.3$ & $J-35$ & \\
\hline $\begin{array}{l}\text { Siganus sutor } \\
\text { Acanthuridae }\end{array}$ & ${ }^{\mathrm{a}} 0.6 \pm 0.9$ & $51.5-60.1$ & ${ }^{\mathrm{b}} 18.7 \pm 22.0$ & $27.9-70.0$ & $J-212$ & Yes \\
\hline Acanthurus triostegus & $0.2 \pm 0.6$ & $22.1,35.6$ & $0.1 \pm 0.3$ & 19.6 & $\mathrm{~J}-3$ & \\
\hline *Acanthurus xanthopterus & - & - & $0.1 \pm 0.3$ & 30.5 & $\mathrm{~J}-1$ & \\
\hline \multicolumn{7}{|l|}{ Ostraciidae } \\
\hline Ostracion meleagris & $0.1 \pm 0.3$ & 102 & - & - & A-1 & \\
\hline \multicolumn{7}{|l|}{ Tetraodontidae } \\
\hline Arothron immaculatus & $0.1 \pm 0.3$ & 121 & - & - & $A-1$ & \\
\hline Mean number of species & $8.7 \pm 3.3$ & & $8.5 \pm 3.3$ & & & \\
\hline Mean number of individuals & $23.9 \pm 18.3$ & & $45.6 \pm 35.9$ & & & \\
\hline
\end{tabular}

Asterisks indicate common tropical western Pacific seagrass bed species, based on Jones and Chase (1975) and Nakamura and Sano (2004)

${ }^{a b}$ Means with different letters are significantly different at $P<0.05$ [t-test or Mann-Whitney $U$ test, log $(\mathrm{x}+1)$ transformed]

'Individuals significantly outside normal range listed separately

"Life stage: J, juvenile; A, adult; J (or A)-x indicates total number of juvenile (or adult) individuals collected from the two seagrass beds

"HIn local markets in Mauritius 